which are rare in other parts of the world. South Africa contains more material than can be found anywhere else, and which will prove of undoubted value to the profession here.

James A. Honey, M.D., Cambridge, Mass.

\section{Method of Increasing the Efficiency and Life of the Dry-Cell Battery}

To the Editor:-Some years ago I began to seek for some method of increasing the life and efficiency of dry cells. I at first employed the usual methods (potassium permanganate and sal ammoniac solutions, etc.). These proving unsatisfactory, $\mathrm{I}$ at last hit on the following simple but cheap and satisfactory method:

When my dry battery has become exhausted, I take an ordinary $3 / 8$-inch drill-bit of sufficient length and drill a hole as near as possible to the carbon and between the carbon and the outside zine covering. This hole should reach to within 1 inch of the bottom of the cell, beginning, of course, at the top or sealed part of the battery. I shake out of the cell all loose dust and particles, and place in this hole a $11 / 2$-ounce glass funnel, having a stem not less than $11 / 2$ inches in length, and of sufficient thickness to fit snugly, especially at the upper part of hole already prepared. This will prevent regurgitation of liquids to outside top of cell. Having secured the funnel firmly in the cell, I pour into it until three-fourths full (about an ounce) of chemically pure hydrochloric acid. This will start an immediate reaction and hydrogen and air bubbles containing particles of contents of the cell will regurgitate through the funnel and contents. It will require from eight to twenty-four hours for this reaction to be completed and the hydrochloric acid absorbed. Owing to a tendency for the small funnel to become clogged, it is necessary from time to time to pass a slender wire down through the funnel neck and hole in the cell. After absorption of the acid, I pour water in the funnel just as long as the cell will take it. When the cell has become thoroughly saturated inside, I seal it carefully with ordinary sealing-wax, set aside for twenty-four to fortyeight hours or longer, and test the cell for battery power. If the work has been carefully done, the results will not be disappointing.

I have in use in my office a battery of dry cells whose first efficiency was a life of three months, after which I treated them as above, and they have been in more or less constant use for a little over ten months. At present there is no sign of weakening or deterioration, and their regenerating ability is remarkable. How long they will last $I$ am not prepared to say. They have exceeded my most ardent expectations. I have ceased discarding my old dry cells, and consider them more valuable after a renewal of this kind than when fresh from the hands of the manufacturer.

Edward M. Hanson, Keokuk, Iowa.

\section{A Convenient Source of Carbon Dioxid Snow}

To the Editor:-The treatment of certain dermatoses by earbon dioxid snow-a substitute originally suggested by $\mathrm{Dr}$. Pusey for the less easily obtainable and less easily managed "liquid air"-has now an established place in the armamentarium of the dermatologist. Its common source is from the large cylinder of carbon dioxid furnished to soda-water fountains. This cylinder, although probably the cheapest source, is large, bulky, cumbersome and unsightly for office use, besides being somewhat clumsy for handling. I have recently found a convenient substitute for this; it is the small cylinder containing liquefied carbon dioxid sold for the inflation of a single automobile tire. It contains sufficient liquefied gas for a large tire-a sufficient quantity, as I have found, to produce enough "snow" for one average dermatologic application. This cylinder is about one inch in diameter and twelve inches in length; it costs $\$ 1$, and when empty is returnable, being credited to the amount of 20 cents toward a new tube. Its manipulation, for either tire inflation or "snow"-making, requires a handle with valve and small hose attachment, which costs $\$ 2$; this can, of course, be used indefinitely.

Henry W. Stelwagon, Philadelphia.

\section{An Envelope Powder Shaker}

To the Editor:-Many physicians and surgeons find it difficult to apply antiseptic powders to wounds properly. A powder blower that will apply the powder evenly, lightly and not wastefully, over the edges of wounds has not yet been offered to the public. Some surgeons use a pledget of cotton with dressing forceps, but this is unsatisfactory as it requires that the powder be poured out on a paper. I have used an envelope for a number of years with much satisfaction and a great saving of powder. It is used as follows: Place 15 or 20 grains of any powder, the finer the better, in an ordinary druggists" prescription envelope, which should then be sealed tightly and the tip of one of the corners torn off. Now take up the envelope between the thumb and fingers, gently press the sides so as to make a little air space and tap on the center of it with the tip of the index finger. This operation will blow out a very fine cloud of the powder and by holding it close to the wound it will take but a few taps with the finger to cover the wound with the finest coating possible. When a corner has been thus used it may, by using the handle of a knife, be turned down tight, and the next time another corner may be torn off, as the crimped corner interferes with the ejection of the powder. I have dressed many large wounds several times without using more than 15 grains of powder and one envelope.

S. A. Newman, M.D., Cassville, Mo.

\section{Queries and Minor Notes}

Anonymous Communications will not be noticed. Every letter must contain the writer's name and address, but these will be omitted, on request.

\section{HISTORY OF SEROTHERAPY}

To the Editor:-I desire to obtain a history of serotherapy. Can you direct me to such a publication?

W. S. Devine, Marshalltown, Iowa.

ANSWER.-Dr. Ludvig Hopf's "Immunität und Immunisirung : Fine medicinisch-historische Studie," 95 pages, Tübingen, Franz Pietzcker, 1902, gives an excellent historical account of the theories of infection and immunity, including the development of serotherapy up to that date. The more recent developments are scat. tered through the literature. Wright's "Studies on Immunization," Constable, London, includes the main papers published by Wright on the opsonins, and contains about 500 pages. Sauerbeck's "Neue Tatsachen und Theorien in der Immunitätsforschung," published in 1907 in the Lubarsch-Ostertag Ergebnisse, and also as a separate monograph, by J. F. Bergmann, Wiesbaden, gives a thorough review particularly of the opsonins and aggressins (over 300 pages).

\section{INJECIION TREAIMENT FOR HEMORRHOIDS}

To the Editor:-Kindly give list of works on the injection treatment for hemorrhoids.

L. A. W.

ANSwer.-We know of no special book on the injection treatment of hemorrboids, but it is described in the standard works on rectal diseases, among which may be mentioned:

Agnew : Rectal Diseases, L. S. Matthews \& Co., 2623 Olive St., St. Louis, Mo.

Allingham: Diseases of the Rectum, William Wood \& Co. 51 Fifth Ave., New York.

Andrews: Rectal and Anal Surgery, Chicago Medical Book Co., Honoré and Congress Sts., Chicago, Ill.

Ball: Diseases of Rectum and Anus, W. 'T. Keener \& Co., 90 Wabash Ave.. Chicago. Ill. (This tirm has gone out of buss. ness.)

Gant : Diseases of the Rectum and Anus, E. A. Davis Co., 191/ Cherry St., Philadelphia, Pa.

Goodsall and Miles: Diseases of the Anus and Rectum, Long. mans, Greene \& Co., 91-93 Fifth Ave., New York.

Kelsey: Surgery of the Rectum, William Wood \& Co., 51 Fifth Ave., New York.

Mason: Office Treatment of Rectal Diseases. L. S. Matthervs \& Co., 2623 Olive St., St. Louis, Mo.

Mathews: Diseases of the Rectum, Etc., D. Appleton \& Co.. 436 Fifth Ave, New York.

Tuttle: Diseases of the Rectum, D. Appleton \& Co., 436 Fifth Ave., New York.

Wallis: Surgery of Rectum, William Wood \& Co., 51 Fifth Ave. New York.

These books can be obtained through medical bouksellers generally. 